\title{
UJI AKTIVITAS ANTIBAKTERI EKSTRAK JAMUR TIRAM PURIH (PLEUROTUS OSTREATUS) TERHADAP BAKTERI STREPTOCOCCUS MUTANS PENYEBAB \\ KARIES GIGI
}

\author{
Kartika Khairani*, Busman*, Edrizal ${ }^{* *}$ \\ *Bagian Oral Biologi, FKG Universitas Baiturrahmah \\ ** Bagian Ortodonti, FKG Universitas Baiturrahmah \\ Jl. Raya By. Pass KM. 14 Sei Sapih, Padang \\ Email: khairani_kartika@yahoo.co.id
}

\section{KATA KUNCI}

Ekstrak jamur tiram putih, zona hambat, bakteri Streptococcus mutans.

\section{KEYWORDS}

white oyster mushroom extract, inhibition zone, Streptococcus mutans

\begin{abstract}
ABSTRAK
Masalah kesehatan gigi dan mulut yang banyak terjadi di masyarakat saat ini adalah karies gigi. Streptococcus mutans merupakan salah satu mikroorganisme spesifik penyebab karies gigi. Pencegahan karies dapat dilakukan dengan penggunaan bahan antimikroba yang berasal dari alam seperti jamur tiram putih. Jamur tiram putih (Pleurotus ostreatus) merupakan jamur yang memiliki kandungan nutrisi yang lebih tinggi dibandingkan dengan jamur kayu lainnya. Penelitian ini bertujuan untuk mengetahui adanya aktivitas antibakteri ekstrak jamur tiram putih terhadap bakteri Streptococcus mutans penyebab karies gigi. Jenis penelitian yang digunakan adalah eksperimental Laboratorium dengan metode disc diffusion dengan mengukur zona hambat yang mengindikasikan adanya hambatan pertumbuhan bakteri Streptococcus mutans oleh ekstrak jamur tiram putih. Konsentrasi ekstrak jamur tiram putih yang digunakan dan rerata diameter zona hambat yaitu $10 \%(10,55 \mathrm{~mm}), 20 \%(12,12 \mathrm{~mm}), 40 \%(12,16 \mathrm{~mm})$, $60 \%(13,63 \mathrm{~mm})$ dan $80 \%(10,91 \mathrm{~mm})$ dengan kontrol positif sebagai pembanding adalah amoxicillin $32 \mathrm{~g} / \mathrm{ml}$. Hasil penelitian di uji menggunakan uji One Way Anova, diketahui rerata diameter zona hambat paling besar adalah pada konsentrasi $60 \%(13,63 \mathrm{~mm})$ dengan kategori kuat.
\end{abstract}

\begin{abstract}
Dental caries is one of the oral health problems that can occur in community. Streptococcus mutans is one of the specific microorganisms that caused dental caries. The dental caries prevention can be done by using natural antimicrobial agent such as white oyster mushroom (Pleurotusostreatus). White oyster mushroom is the mushroom that has higher nutritional value to be compare with other wood mushrooms. This study aims to discover antibacterial activity of white oyster mushroom extract toward Streptococcus mutans in caries. This study was experimental laboratory with disc diffusion method by measuring inhibitory zone that indicated the inhibitionin the growth of Streptococcus mutans by white oyster mushroom extract. The concentration of the extracts used in this study and the average inhibition zone diameter were $10 \%(10.55 \mathrm{~mm}), 20 \%(12.12 \mathrm{~mm}), 40 \%$ $(12.16 \mathrm{~mm}), 60 \%(13.63 \mathrm{~mm})$, and $80 \%(10.91 \mathrm{~mm})$ with amoxicillin 32
\end{abstract}


$\mu \mathrm{g} / \mathrm{ml}$ as positive control. The result was analyzed by using one way ANOVA. The largest average inhibition zone diameter was at $60 \%$ concentration $(13.63 \mathrm{~mm})$ with strong category.

\section{PENDAHULUAN}

Gigi dan mulut merupakan investasi bagi kesehatan seumur hidup. Peranannya cukup besar dalam mempersiapkan zat makan sebelum absorbsi nutrisi pada saluran pencernaan, disamping fungsi psikis dan sosial ${ }^{1}$. Dalam rongga mulut seseorang mengandung berbagai macam bakteri salah satunya Streptococcus mutans yang bersifat kariogenik dan merupakan penyebab utama karies gigi ${ }^{2}$.

Karies gigi merupakan penyakit yang paling banyak dijumpai di rongga mulut, sehingga merupakan masalah utama kesehatan gigi dan mulut ${ }^{1}$. Pembentukan karies gigi disebabkan oleh asam yang dihasilkan oleh aksi mikro organisme terhadap karbohidrat. Reaksi ini ditandai dengan dekalsifikasi komponen organik dilanjutkan oleh disintegrasi substansi organik yang berasal dari gigi atau disebut dengan teori asidogenik ${ }^{3}$.

Karies gigi merupakan masalah kesehatan gigi yang dapat dicegah. Pencegahan karies gigi dapat menurunkan angka kejadian karies gigi ${ }^{4}$. Pencegahan karies gigi dapat dilakukan dengan berbagai cara, diantaranya dengan penggunaan bahan antimikroba untuk mengurangi jumlah bakteri penyebab karies pada rongga mulut ${ }^{5}$. Bahan antimikroba yang berasal dari alam saat ini banyak digunakan dan menjadi kajian penting akibat semakin menurunnya efektivitas obat kimia karena efek samping dan resistensi. Penggunaan obat yang berasal dari alam lebih banyak digunakan karena lebih aman dan mudah didapat ${ }^{6,7}$.Indonesia sebagai negara tropis memiliki kekayaan akan flora, yang diantaranya berkhasiat sebagai tanaman obat $^{8}$. Salah satunya adalah jamur tiram putih yang berkhasiat untuk pengobatan.

Jamur tiram putih (Pleurotus ostreatus) merupakan jamur pangan yang menempati posisi kedua pada pasar jamur dunia. Jamur ini memiliki kandungan nutrisi yang lebih tinggi dibandingkan dengan jamur kayu lainnya. Jamur ini mengandung senyawa golongan terpenoid, saponin, dan steroid. Beberapa saponin bekerja sebagai antimikroba. Saponin bekerja sebagai antibakteri dengan mengganggu stabilitas membran sel bakteri sehingga menyebabkan sel bakteri lisis ${ }^{9}$.

Penelitian sebelumnya oleh Zahro dan Rudiana (2013) tentang ekstrak kasar saponin jamur tiram putih terhadap Staphylococcus aureus dan Escherichia coli dengan konsentrasi yaitu $50 \mathrm{mg} / \mathrm{mL}, 100$ $\mathrm{mg} / \mathrm{mL}, \quad 150 \mathrm{mg} / \mathrm{mL}, \quad 200 \mathrm{mg} / \mathrm{mL}, \quad 250$ $\mathrm{mg} / \mathrm{mL}$, dan $300 \mathrm{mg} / \mathrm{mL}^{10}$. Aktivitas antibakteri tertinggi ekstrak kasar saponin dari jamur tiram putih (Pleurotus ostreatus) terhadap Staphylococcus aureus dan 
Escherichia coli ditunjukkan pada konsentrasi $300 \mathrm{mg} / \mathrm{mL}$.

Berdasarkan uraian diatas peneliti ingin melakukan penelitian tentang aktivitas antibakteri jamur tiram putih terhadap bakteri Streptococcus mutans. Berdasarkan penelitian literatur, belum ada literatur lain yang meneliti tentang aktivitas antibakteri ekstrak jamur tiram putih (Pleurotus ostreatus) terhadap bakteri Streptococcus mutans.

\section{METODE}

Jenis penelitian yang digunakan dalam penelitian ini adalah eksperimental laboratorium. Penelitian dilakukan di Laboratorium Kimia Kopertis Wilayah X (Sumatera Barat, Riau, Jambi dan Kepulauan Riau) Padang, Sumatera Barat dan dilaksanakan pada bulan Februari - April 2017. Sampel pada penelitian ini adalah bakteri Streptococcus mutans.

Alat yang digunakan dalam penelitian ini disterilkan terlebih dahulu.LAF (Laminar Air Flow),botol gelap 2,5 liter, pinset, gunting, pisau, oven, wadah, timbangan analitik, vorteks,rotary evaporator, tabung erlenmeyer, hot plate, corong, cawan petri, jarum ose, drillglass, autoklaf, tabung reaksi, rak tabung reaksi, penjepit tabung reaksi, jangka sorong digital, corong, beker glass, labu ukur $10 \mathrm{ml}$, sendok kaca, lampu spiritus, inkubator, cotton bud steril, plastik wrap, kapas, kain kasa dan kertas saringwathman.
Bahan yang digunakan adalah jamur tiram putih (Pleurotus ostreatus), pelarut etanol 96\%, bakteri Streptococcus mutans, alkohol 70\%, media Mueller Hinton Agar (MHA), aquades, $\mathrm{NaCl}$ 0,9\%, handscoon, masker, aluminium foil, kasa steril, tisu, kapas, dimethyl sulfoxide (DMSO) dan amoxicillin sediaan bubuk.

Jamur tiram putih (Pleurotus ostreatus) digunakan sebanyak 6 kilogram dan diperoleh dari Trila Farm budidaya jamur tiram dan jamur kuping yang ada di jalan Tabek Batu Aie Pacah, Padang. Pembuatan ekstrak jamur tiram putih dilakukan dengan proses maserasi menggunakan etanol 96\% yang awalnya dibersihkan dan dipotong kecil-kecil kemudian dikeringkan dengan cara diangin-anginkan dan kemudian dihaluskan. Bakteri Streptococcus mutans yang digunakan dalam penelitian ini merupakan bakteri biakan murni yang diperoleh dari Laboratorium Mikrobiologi Universitas Indonesia.

Pembuatan suspensi Streptococcus mutans dengan mencampur larutan fisiologis $(\mathrm{NaCl}$ 0,9\%) kedalam tabung reaksi, lalu ditambahkan 1 ose bakteri Streptococcus mutans dan bagian mulut tabung reaksi ditutup dengan kapas lalu divortex selama 1 menit.

Kontrol positif yang digunakan adalah amoxicillin, dibuat dengan menggunakan sediaan bubuk obat amoxicillin yang mengacu pada minimal inhibitory concentration (MIC) amoxicillin terhadap 
Streptococcus mutans, yakni $32 \mathrm{~g} / \mathrm{ml}$ yang dicampur dengan pelarut DMSO hingga homogen ${ }^{11}$. DMSO sebagai kontrol negatif digunakan karena dalam pembuatan kontrol positif dan pembuatan konsentrasi ekstrak jamur tiram putih menggunakan DMSO sebagai pelarut.

Metode pengujian yang digunakan adalah dengan metode disc diffusion. Media MHA yang sudah disediakan pada cawan petri ditanam suspense bakteri secara merata. Kertas cakram yang sebelumnya sudah direndam ke dalam masing-masing konsentrasi dan kelompok kontrol selama 15 menit diambil menggunakan pinset dan diletakkan pada media yang sudah ditanam bakteri. Setelah itu cawan petri dibungkus menggunakan plastik wrap dan diinkubasi pada oven dengan suhu $37^{\circ} \mathrm{C}$ selama 24 jam.

Pengamatan dilakukan setelah 24 jam masa inkubasi. Zona bening merupakan petunjuk kepekaan bakteri terhadap bahan antibakteri yang digunakan sebagai bahan uji dan dinyatakan dengan diameter zona hambat. Zona hambat yang terbentuk disekitar sumur diukur diameter vertikal dan diameter horizontal dengan satuan millimeter (mm) dengan menggunakan jangka sorong.

Hasil pengukuran diameter zona hambat disajikan dalam bentuk tabel, kemudian dianalisis secara deskriptif dan statistik dengan menggunakan aplikasi SPSS Uji One Way ANOVA (Analysis of Variance).

\section{HASIL}

Hasil pengukuran diameter zona hambat ekstrak jamur tiram putihdengan konsentrasi $10 \%, 20 \%, 40 \%, 60 \%$ dan $80 \%$ serta kontrol positif dengan menggunakan amoksisilin dapat dilihat pada Tabel 1.

Tabel 1. Rerata hasil perhitungan aktivitas antibakteri ekstrak jamur tiram putih (Pleurotus ostreatus) terhadap bakteriStreptococcus mutanspenyebab karies

\begin{tabular}{lcl}
\hline Konsentrasi & Rerata $(\mathrm{mm})$ & Kategori \\
\hline $10 \%$ & 10.5500 & Kuat \\
$20 \%$ & 12.1250 & Kuat \\
$40 \%$ & 12.1625 & Kuat \\
$60 \%$ & 13.6375 & Kuat \\
$80 \%$ & 10.9125 & Kuat \\
Kontrol (+) & 28.0000 & Sangat Kuat \\
\hline
\end{tabular}

Tabel 1. menunjukkan bahwa rerata diameter zona hambat tertinggi berada pada konsentrasi $60 \%$ yaitu $13,63 \mathrm{~mm}$ dengan kategori kuat, sedangkan rerata diameter zona hambat paling rendah pada konsentrasi $10 \%$ yaitu $10,55 \mathrm{~mm}$ dengan kategori kuat. Artinya aktivitas anti bakteri ekstrak jamur tiram putih (Pleurotus ostreatus) terhadap bakteri Streptococcus mutans paling efektif pada konsentrasi $60 \%$. Rerata diameter zona hambat oleh kontrol positif dengan menggunakan amoxicillin yaitu $28 \mathrm{~mm}$ dengan kategori sangat kuat dan pada kontrol negatif menggunakan dimethyl sulfoxide (DMSO) tidak terdapat diameter zona hambat.

\section{PEMBAHASAN}

Berdasarkan hasil uji statistik yang telah dilakukan dapat disimpulkan bahwa ekstrak jamur tiram putih (Pleurotus ostreatus) memiliki aktivitas antibakteri yang dinilai 
melalui adanya daerah hambat pertumbuhan pada bakteri uji Streptococcus mutans.

Hasil dari pengujian ekstrak jamur tiram putih (Pleurotus ostreatus) tehadap bakteri Streptococcus mutans diperoleh rerata diameter zona hambat pada konsentrasi $10 \%$ adalah $10,55 \mathrm{~mm}, 20 \%$ sebesar $\quad 12,12$ $\mathrm{mm}, 40 \%$ sebesar $12,16 \mathrm{~mm}, 60 \%$ sebesar $13,63 \mathrm{~mm}, 80 \%$ sebesar 10,91 mm, kontrol positif dengan menggunakan amoxicillin sebesar 28,00 mm dan kontrol negatif dengan menggunakan dimethyl sulfoxide (DMSO) sebesar $0,00 \mathrm{~mm}$.Rerata diameter zona hambat yang diperoleh dikategorikan menurut Davis \& Stout (1976) pada Tabel $2^{12}$.

Tabel 2. Kategori aktivitas antibakteri menurut Davis \& Stout (1976)

\begin{tabular}{ll}
\hline Aktivitas antibakteri & $\begin{array}{l}\text { Diameter zona } \\
\text { hambat }(\mathrm{mm})\end{array}$ \\
\hline Lemah & $<5$ \\
Sedang & $5-10$ \\
Kuat & $10-20$ \\
Sangat kuat & $>20$ \\
\hline
\end{tabular}

Berdasarkan kategori tersebut menunjukkan kekuatan daya hambat ekstrak jamur tiram putih (Pleurotus ostreatus) terhadap bakteri Streptococcus mutans pada semua konsentrasi termasuk kategori kuat.

Aktivitas antibakteri yang tergolong kuat pada setiap konsentrasi ekstrak jamur tiram putih (Pleurotus ostreatus) diduga karena adanya kandungan senyawa saponin. Mekanisme kerja saponin sebagai antibakteri adalah penghambatan kolonisasi bakteri, menurunkan tegangan permukaan sehingga mengakibatkan naiknya permeabilitas atau kebocoran sel dan mengakibatkan senyawa intraseluler dan berbagai komponen penting dari dalam sel bakteri seperti protein, asam nukleat dan nukleotida keluar atau dengan cara melisiskan membran sel bakteri ${ }^{13,14,15}$.

Saponin bersifat surfaktan yang berbentuk polar sehingga akan memecah lapisan lemak pada membran sel yang pada akhirnya menyebabkan gangguan permeabilitas membran sel, hal tersebut mengakibatkan proses difusi bahan atau zat-zat yang diperlukan oleh bakteri dapat terganggu, akhirnya sel membengkak dan pecah ${ }^{16}$. Senyawa ini berdifusi melalui membran luar dan dinding sel yang rentan, lalu mengikat membran sitoplasma dan mengganggu dan mengurangi kestabilan itu. Hal ini menyebabkan sitoplasma bocor keluar dari sel yang mengakibatkan kematian sel. Agen antimikroba yang mengganggu membran sitoplasma bersifat bakterisida ${ }^{17}$. Hal ini yang menyebabkan terbentuknya zona hambat pada setiap konsentrasi ekstrak jamur tiram putih, disebabkan senyawa saponin mengganggu permeabilitas membran sel bakteri streptococcus mutans sehingga sel membengkak dan mengakibatkan bakteri lisis.

Kontrol positif pada penelitian ini menggunakan amoxicillin dengan rerata diameter zona hambat terhadap pertumbuhan bakteri Streptococcus mutans tergolong ke dalam kategori sangat kuat yaitu $28 \mathrm{~mm}$. Kontrol positif dibuat dengan menggunakan sediaan bubuk obat amoxicillin yang 
mengacu pada minimal inhibitory concentration (MIC) amoxicillin terhadap Streptococcus mutans, yakni $32 \mathrm{~g} / \mathrm{ml}$ yang dicampur dengan pelarutDMSO hingga homogen ${ }^{11}$.

Amoxicillin digunakan sebagai kontrol positif karena merupakan golongan dari antibiotik penisilin dengan spektrum luas, sehingga dapat digunakan untuk menghambat pertumbuhan bakteri gram positif dan negatif ${ }^{18}$. Kontrol negatif yang digunakan pada penelitian ini adalah dimethyl sulfoxide (DMSO). DMSO sebagai kontrol negatif digunakan karena dalam pembuatan kontrol positif dan pelarut untuk konsentrasi ekstrak jamur tiram menggunakan pelarut DMSO.

Dibandingkan dengan penelitian Zahro dan Rudiana (2013) yang mendapatkan hasil semakin tinggi konsentrasi maka semakin besar zona hambat yang terbentuk, namun pada penelitian ini setelah konsentrasi mencapai zona hambat yang efektif terjadi penurunan zona hambat pada konsentrasi $80 \%$ yaitu menjadi $10,91 \mathrm{~mm}$. Hal ini terjadi diduga karena zat antibakteri dari ekstrak tidak mampu berdifusi ${ }^{19}$. Konsentrasi ekstrak yang terlalu pekat membuat ekstrak tidak mampu berdifusi dengan maksimal. Konsentrasi ekstrak yang tinggi menyebabkan ekstrak terjadi kejenuhan yang menyebabkan zat-zat aktif dalam ekstrak tidak dapat larut dengan sempurna ${ }^{20}$. Sehingga senyawa yang ada pada ekstrak jamur tiram putih tidak bekerja dengan efektif dan menyebabkan aktivitas antibakteri yang minimal dan zona hambat yang kecil.

Aktivitas zona hambat pada penelitian Zahro dan Rudiana (2013) jika dibandingkan ekstrak jamur tiram putih terhadap bakteri streptococcus mutans pada penelitian ini, didapatkan simpulan bahwa ekstrak jamur tiram putih lebih memiliki aktivitas antibakteri yang baik terhadap streptococcus mutans dibanding terhadap bakteri Staphylococcus aureusdan Escherichia coli, yang dapat dilihat dari hasil diameter zona hambat yang terbentuk lebih besar terhadap bakteri streptococcus mutans.

\section{SIMPULAN}

Berdasarkan hasil penelitian dan analisis data dapat disimpulkan bahwa ada aktivitas antibakteri dari ekstrak jamur tiram putih terhadap bakteri Streptococcus mutans penyebab karies. Aktivitas antibakteri ekstrak jamur tiram putih (Pleurotus ostreatus) terhadap bakteriStreptococcus mutansyang paling efektif pada konsentrasi $60 \%$ dengan memiliki rerata zona hambat paling tinggi dibanding konsentrasi lainnya yaitu 13,63 mm dengan kategori kuat.

\section{DAFTAR PUSTAKA}

1. Tampubolon, N. S. 2006. Dampak Karies Gigi dan Penyakit Periodontal Terhadap Kualitas Hidup. Dentika Dental Jounal. 6(1): 184-188.

2. Anggraeni, A., Anita, Y. dan Intan, N. 2005. Perlekatan koloni Streptococcus mutans pada permukaan resin komposit sinar tampak. Dental Journal (Majalah Kedokteran Gigi). 38(1): 8-11. 
3. Ramayanti, S. dan Idral, P. 2013. Peran Makanan terhadap Kejadian Karies Gigi. Jurnal Kesehatan Masyarakat. 7(2): 89-93.

4. Fatarina, N. F., Rahayu, A. dan Wulandari, M. 2007. Hubungan antara Frekuensi Menggosok Gigi, Cara Menggosok Gigi, dan Bentuk Sikat Gigi dengan Status Kebersihan Gigi dan Mulut pada Siswa Kelas IV-V SDN Karangroto 04 Kecamatan Genuk Kota Semarang Tahun 2007. PhD thesis. Universitas Muhammadiyah Semarang. hal. 2.

5. Sulianti, T. 2012. Perbedaan Efek Antimikroba Papacarie dan Papain Terhadap Streptococcus mutansIn Vitro. Tesis. Program Pendidikan Dokter Gigi Spesialis Konservasi Gigi Universitas Indonesia. Jakarta.hal. 2.

6. Sari, Y. D., Sitti, N. D. dan Laela, H. N. 2010. Uji Aktivitas Antibakteri Infusa Daun Sirsak (Annona muricata L.) Secara in Vitro Terhadap Staphylococcus aureus ATCC 25923 dan Escherichia coli ATCC 35218 serta Profil Kromatografi Lapis Tipisnya. KES MES. hal. 218-238.

7. Rusmiati, D., Sri, A.F. K., Yasmiwar, S. dan Sulistianingsih. 2007. Pemanfaatan Kubis (Brassica olerace var. capitata alba) sebagai Kandidat Antikeputihan. Laporan Penelitian. Fakultas Farmasi Universitas Padjadjaran.Bandung.hal. 2.

8. Nursanty, R. dan Zumaidar. 2009. Potensi Antibakteri Beberapa Tumbuhan Obat Tradisional. Biologi FMIPA Unsyiah Darussalam. Banda Aceh: 443-450.

9. Sari, I. R. M. 2012. Uji Aktivitas Antioksidan Ekstrak Jamur Pleurotus ostreatus dengan Metode DPPH dan Identifikasi Golongan Senyawa Kimia dari Fraksi Teraktif. Skripsi. Fakultas Matematika dan Ilmu Pengetahuan Alam Universitas Indonesia. Jakarta. hal. 37.

10. Zahro, L. dan Rudiana, A. 2013. Uji Efektifitas Antibakteri Ekstrak Kasar Saponin Jamur Tiram Putih (Pleurotus ostreatus) Terhadap Staphylococcus aureus dan Escherichia coli. UNESA Journal of Chemistry. 2(3): 2-7.

11. Kawengian, S. A. F., Jane, W. dan Michael, A.L. 2017. Uji daya hambat ekstrak daun serai (Cymbopogon citratus L) terhadap pertumbuhan Streptococcus mutans. Jurnal eGigi (Eg). 5(1): 1-5.

12. Davis, W.W. dan Stout, T.R. 1971. Disc Plate Methods of Microbiological Antibiotic Assay. Microbiology. 22(4):659-665.

13. Ngoci, N.S., Evalyne, M., and Ng'ang'a, E., 2013. Screening for anti-bacterian activity and phytochemicals of Leonotis nepetifolia leaves methanol extract. Journal of Biotechnological Sciences. JBS; 1(1):15-21.

14. Ganiswarna, S. G. 1995. Farmakologi Dan Terapi. Jakarta: Gaya Baru. hal. 572-573.

15. Nuria, M.C., Arvin, F., Sumantri. 2009. Uji Aktivitas Antibakteri Ekstrak Daun Jarak Pagar (Jatropha curcas L) terhadap Bakteri Staphylococcus aureus ATCC 25923, Escherichia coli ATCC 25922 dan Salmonella typhi ATCC 1408. Jurnal Ilmuilmu Pertanian 5(2): 26-37.

16. Robin, R.J., A.J. Parr, J.n. Walton, 1991. Studies on the Biosynthesis of Tropane Alkaloid In Dature Stramonium L. TransformedmRoot Culture On The Relative Contribution of L. Anginine and $L$. Ormithinelo The FormationOf The Tropanering. Planta. 183: 196-201.

17. Cavalieri, S.J., I.D. Rankin., R.J. Harbeck., R.S. Sautter., Y.S. McCarter., S.E. Sharp., J.H. Ortez., dan C.A. Spiegel. 2005. Manual of Antimicrobial Susceptibility Testing. American Society for Microbiology, USA. hal.7.

18. Wahyuni, L. S. 2014. Uji Aktivitas Antibakteri Ekstrak Kubis ( Brassica oleracea L. var capitata L.) Terhadap Bakteri Escherichia coli. Skripsi. Fakultas Kedokteran dan Ilmu Kesehatan UIN Syarif Hidayatullah. Jakarta. hal. 29.

19. Dani, I. W., Kiki, N. dan Cut, F. Z. 2012. Penghambatan Pertumbuhan Aspergillus flavus dan Fusarium monilifome oleh Ekstrak Salam (Eugenia polyantha) dan Kunyit (Curcuma domestica). Siantica Biologi. 1(1): 1-7.

20. Maleki, S., Seyyednejad S.M., Damabi M.N., dan Motamedi H. 2008. Antibacterial activity of thefruits of Irianian Torilis leptophylla againstsome clinical pathogens. Pakistan Journal of Biological Sciences. 11(9): 12861289 . 